\title{
0 voto de saias: \\ a Constituinte de 1934 \\ e a participação das mulheres na política
}

\author{
RITA de CÁsSIa BARBosa de ARAújo
}

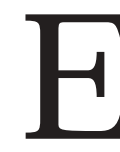

m 26 janeiro de 1933, o Diario de Pernambuco iniciou a publicação de uma enquete, realizada junto a "ilustres senhoras e senhorinhas da sociedade pernambucana" ${ }^{1}$. D ezenove mulheres colaboraram com o jornal, respondendo à indagação "A quem deverá caber a representação da mulher pernambucana na futura constituinte?", sendo o resultado da última consulta publicado em 4 de abril daquele mesmo ano. A pesquisa, inicialmente pensada para restringir-se às pernambucanas, acabou alcançando os E stados vizinhos da Paraíba e de A lagoas. Foram incorporadas à amostra duas associações de mulheres: a Federação Pernambucana para o Progresso Feminino e a Liga Eleitoral C atólica, que funcionavam no Recife, perfazendo o total de vinte e duas matérias jornalísticas dedicadas ao assunto.

A idéia de realizar a pesquisa ouvindo exclusivamente mulheres, bem como sua temática, execução e publicação eram, em si mesmas, uma inovação - e não apenas no âmbito da imprensa jornalística. Ela era expressão, ao mesmo tempo que concretude, de algo mais convulsivo e de maior alcance econômico, social, cultural e político, que transcorria no seio da sociedade brasileira de então. Fato, aliás, que não passou desapercebido de ao menos uma das inquiridas, a doutora Albertina Correia de L ima, advogada, formada na F aculdade de Direito do R ecife e residente na capital paraibana. O Diario apresentou-a como "figura de marcado relevo nos círculos intelectuais da Paraíba" e "descendente de uma família de homens ilustres", a exemplo do irmão João da M ota, também advogado e líder popular. Partidária da emancipação política das mulheres, cujas conquistas dizia acompanhar com vivo interesse, nutria igual simpatia pela enquete realizada pelo D iario, sinalizando perceber a iniciativa como mais uma manifestação da luta das mulheres pela ampliação de seus direitos civis e políticos e pela conquista de novos espaços na sociedade.

0 presente artigo, que podemos situar no campo da chamada microhistória, pretende anal isar os dados da referida enquete, publicados no Diario de Pernambuco, os quais permaneceram desconhecidos para as gerações que se seguiram àquela e inexplorados como objeto de estudos até o presente. Tratando-se de uma reflexão inicial sobre o tema da mulher e das mudanças em torno do lugar que ocupava ou deveria ocupar na sociedade brasileira, nos anos de 1930, a análise busca identificar social e culturalmente o perfil das entrevistadas, bem como 
pontuar os interesses e o universo de valores por onde gravitavam as idéias dessas mulheres, suas percepções em relação à situação da mulher na sociedade e aos movimentos feministas, no país e no mundo, assim como suas expectativas quanto ao futuro próximo da nação.

Conforme expunha claramente o jornal, a consulta dirigia-se a "senhoras e senhorinhas ilustres da sociedade", àquelas de "mais relevo no seio de nossa sociedade", às "figuras de mais realce em nossos círculos sociais". Tais predicados não deixavam dúvidas quanto ao alcance social da pesquisa: foram ouvidas apenas mulheres da elite social urbana do Recife, de J oão Pessoa e uma única senhora de $M$ aceió. Ainda que se restringisse ao espaço urbano, onde o questionamento sobre a "moderna função da mulher" na sociedade realmente ganhava corpo e sentido, ficavam excluídas as mulheres das camadas sociais urbanas economicamente desfavorecidas, como as operárias das fábricas, as empregadas no comércio, as funcionárias públicas dos escalões inferiores, as donas de casa pobres, as integrantes dos movimentos sindicais e as dos partidos operários.

$M$ as, além deste primeiro e significativo recorte, que tomava por base a classe social a que pertenciam as entrevistadas, a enquete particularizava ainda mais a amostra, levando em conta a formação escolar da inquirida, sua vida socioprofissional e penetração no mundo social e nos círculosfemininos. 0 s depoimentos registravam, assim, o pensamento de pintoras, pianistas, escritoras, poetisas, professoras, principalmente das Escolas $\mathrm{N}$ ormais, formadoras de opinião que costumavam publicar artigos em jornais locais, médicas, acadêmicas, bacharéis em D ireito, advogadas algumas delas, funcionárias públicas, integrantes de associações civis e católicas que lutavam pelos interesses da mulher. O piniões, enfim, de mulheres escolarizadas, letradas e cultas, que possuíam uma vida social ativa, atuando na esfera pública, muitas das quais inseridas no mercado de trabalho formal, desenvolvendo atividades remuneradas fora da esfera doméstica. Agiam deste modo não por necessidade econômica, de garantir a sua sobrevivência e a dos seus; mas por razões de outra ordem, que poderíamos situar como social, cultural, política, estética, psíquica, comportamental e até mesmo por modismo.

Recorrendo aos escritos de Edwiges de Sá Pereira, líder do movimento feminista em Pernambuco, segundo seu estudo Pela mulher, para a mulher, de 1931, as informantes do Diario enquadravam-se na primeira, dentre as três categorias de mulher identificadas no Brasil de então ${ }^{2}$. M ulheres brancas, oriundas das antigas classes senhorais, que viveram o ócio proporcionado pela sociedade escravocrata; hierarquicamente superiores às demais, haja vista o critério de renda e riqueza em que se baseavam os valores norteadores da pirâmide social. M ulheres que foram tocadas, entretanto, pelo afã da campanha abolicionista, que as despertou de sua indolência e passividade, impelindo-as para novas lutas e conquistas, lançando-as para além do limitado espaço doméstico e familiar a que praticamente limitavam suas existências. Integradas à esfera da vida pública, partícipes das lutas políticas mais gerais de seu tempo, desenvolveram maior espí- 
rito de sociabilidade e sentiram necessidade de ampliar seus conhecimentos e cultura ${ }^{3}$.

Poderíamos especular sobre o porquê de o jornal assim proceder: seria por julgá-las as únicas capazes de emitir parecer abalizado sobre o problema? $\mathrm{O} u$ queria o Diario reforçar o componente de classe social que a questão encerrava, divulgando valores e ideologias ligados aos movimentos femininos e feministas, presentes no seio das camadas sociais urbanas mais elevadas, cultas e letradas? Fosse ou não esta última intenção consciente, o fato é que, ao difundi-los, os editores do jornal reforçavam o ponto de vista e os interesses dessas camadas, concorrendo para delimitar o alcance cultural e político da questão e para definir os sujeitos sociais a quem, legitimamente, segundo pensavam, cabia discutir sobre assunto tão palpitante, atuar na so ciedade em defesa dos interesses da mulher e contribuir para a redefinição do Estado nacional.

A enquete fora desenvolvida nos meses que antecederam imediatamente as eleições de 3 de maio de 1933, em que deveriam ser escolhidos os representantes dos vários segmentos da so ciedade para compor a Assembléia $\mathrm{N}$ acional Constituinte de 1934. O riginária da Revolução de outubro de 1930, embora não se tenha realizado como uma sua conseqüência imediata, a Constituinte de 1934 trazia como traço singular o fato de ser fruto de pressões de setores que, mesmo havendo participado do movimento revolucionário, encontravam-se à margem do aparel ho de Estado. Figurando como exigência da contra-revolução, em um primeiro momento, a proposta de convocar uma assembléia constituinte foi encampada pelo G overno Provisório, que tinha por chefe G etúlio Vargas, que Ihe atribuiu novo significado, apresentando-a como intenção legítima de toda a nação 4 .

O Governo Provisório autodefinia-se como um poder passageiro na vida política do país, havendo de ser substituído pelos legítimos representantes da nação - segundo determinasse a Assembléia $\mathrm{N}$ acional Constituinte. A revisão da legislação eleitoral e a elaboração de um novo código eleitoral, compromisso assumido por G etúlio Vargas, constituíram um dos atos políticos mais importantes do Governo Provisório. O D ecreto no 21.076, de 24 de fevereiro de 1932, regulamentava 0 alistamento e o processo eleitoral no país, nos âmbitos federal, estadual e municipal, trazendo uma série de inovações, dentre as quais se destacava o estabelecimento do sufrágio universal e secreto. M ais ainda, o novo código ampliava o corpo político da nação, concedendo o direito de voto a todos os brasileiros maiores de vinte e um anos, alfabetizados e sem distinção de sexo. As mulheres brasileiras adquiriam assim, pela primeira vez e após árdua luta, cidadania política, contribuindo para o aumento significativo do número de votantes no país ${ }^{5}$.

Eis porque o Diario de Pernambuco concedia-Ihes espaço para manifestarem suas opiniões a respeito da vida política do país, estimuladas pela pergunta de a quem deveria caber a representação da mulher pernambucana, da paraibana e da alagoana, na futura Constituinte. A maioria das respostas, porém, ia muito 
além do que estava sendo efetivamente inquirido; expressão, talvez, de uma ânsia em expor sentimentos e reflexões há muito abafados e pouco prestigiados em uma sociedade até então dominada pelo elemento masculino ${ }^{6}$. A pretexto de divulgar o nome das candidatas de suas preferências ou de expor os atributos que consideravam fundamentais em uma representante mulher na Constituinte, as senhoras e senhorinhas dissertavam sobre assuntos vários, ampliando o campo do debate público sobre a mulher, correlacionando o tema a questões econômicas, sociais, culturais, direitos civis e políticos, dentre outras.

Algumas demonstravam clareza na percepção do momento político vivido pela sociedade brasileira pós-revolucionária. A senhorinha $\mathrm{N}$ air de Andrade, a quem o jornal distinguia pelo pertencimento à família ilustre, pela aprimorada educação, pela fina sensibilidade de mulher aliada a uma rara distinção intel ectual e vivacidade de espírito, dizia sobre o Brasil:

O Brasil ainda convulsionado, por um longo período revolucionário, volta uma folha, oferecendo página em branco para um novo capítulo de sua história político-social.

O s responsáveis pela $D$ itadura acenam de longe [...] prometendo [...] garantindo [...] próxima constituinte.

E os partidos se movimentam, arregimentam forças, numa precipitação, e numa tal dispersão de ordem, que não deixam ver claro, as bases, os princípios talvez ainda $[\ldots]$ inexistentes.

Confundem-se quase... vel has e novas correntes tal a pressa com que pretendem alcançar o mesmo ponto... um labirinto verdadeiro? .

0 momento político era de indefinições. G etúlio Vargas buscava manter o controle sobre o processo de constitucionalização em curso no país. Segmentos e grupos sociais mobilizavam-se, procuravam organizar-se política e partidariamente, em função de interesses mais gerais ou específicos de classes, frações de classes, grupos ou categorias. Discutia-se o destino do país, projeção que, inevitavelmente, assentava-se sobre uma revisão crítica do passado, representado pela República Velha. D os debates políticos públicos, participava agora, e por direito, a mulher. Porém, ainda que reconhecido o direito de a mulher ingressar na vida política do país, através do livre exercício do voto ou como candidata às eleições, sua participação ensejava inúmeras reações negativas, que iam da pura e simples contestação ao questionamento sobre sua capacidade intelectual para bem cumprir tal desiderato.

As ações das feministas, voltadas para conquistas de direitos políticos para a mulher, intensificaram-se em torno de 1918, quando Berta Lutz e um grupo de colaboradoras criaram, no Rio de Janeiro, uma organização chamada Liga para Emancipação I ntelectual da M ulher, que, posteriormente, passou a denominar-se Liga pelo Progresso Feminino. Em 1919, o senador J usto Chermont apresentou projeto de lei estendendo o direito de voto às mulheres, não conseguindo, porém, sua aprovação. Em 1922, devido a novas estratégias de luta, a Federação das 
L igas pelo Progresso Feminino converteu-se na Federação B rasileira para o Progresso Feminino, que, neste mesmo ano, organizou o I Congresso I nternacional Feminista, no Rio de Janeiro. Coube às mulheres do Rio Grande do N orte, 0 pioneirismo na conquista do direito de voto, ainda em 1927, havendo, porém, um retrocesso nas conquistas eleitorais femininas no ano seguinte. A penas em 1932, com o Decreto no 21.076, as mulheres tornaram-se el eitoras efetivas no $\mathrm{Brasi}^{8}$. Conquista que, para Lili Lages, médica alagoana, representava um desdobramento mais que justo e coerente com os ideários da Revolução de 1930:

D e que serviriam as revoluções, promessas de Brasil, anseios de liberdade, se a metade da população permanecesse soterrada em incongruentes preconceitos e inexplicáveis injustiças, que Ihes fazem perder a noção de personalidade própria, o direito de viver como parte ativa do complexo organismo social? ${ }^{9}$

Conquanto se verificasse 0 crescimento do movimento feminista em todo mundo civilizado ocidental, como também no Brasil, onde as asso ciações para o progresso feminino multiplicavam-se a cada $\mathrm{dia}^{10}$, a senhorinha Ana Campos, catedrática da E scola N ormal, via-se compelida a perguntar: "Reconhecida a igualdade de direitos do homem e da mulher, por que traçar-Ihes diferenças, por que negar à mulher o direito do voto, o direito de legislar?" I ndagação a que ela própria respondia: "A cooperação da mulher na concepção das leis, é uma necessidade que se impõe para defesa de seus direitos e participação nas questões de interesse gerais" ${ }^{11}$.

O depoimento da senhora E dna L eite Gueiros, esposa de "ilustre" advogado pernambucano e colaborada de importante jornal local, trazia elementos que ajudam a compor o quadro de referências e valores culturais em que se pautavam as discussões sobre as novas conquistas femininas. A situação da mulher na paisagem social brasileira era fruto de preconceitos ainda predominantes no meio sociocultural, em que lhe era negado "o direito de contribuir de qualquer modo para o bem da pátria comum". C abia à mulher "provar ao Brasil e como aos seus filhos ranzinzas que a mulher não trouxe consigo apenas, ao aparecer no mundo, a função de procriar. Q ue ela trouxe um cérebro pensador e um espírito que vibra, eis a verdade" ${ }^{12}$.

A procriação, função biológica da mulher, colocava-a em posição de inferioridade em relação ao homem. 0 útero, órgão da histeria e da gravidez, seria responsável por esta condição, condenando-a aos ciclos menstruais, ao parto e à menopausa. $\mathrm{C}$ abia aos defensores da igualdade de direitos entre os sexos e favoráveis ao despertar de uma nova mulher, formular argumentos que rebatessem pontos de vistas que tinham por intento o contrário: provar e manter as desigualdades entre homens e mulheres. Argumentos produzidos nos círculos científicos ou não, que incorporavam outros saberes e repercutiam nas demais esferas da vida so ciocultural, alcançando as integrantes dos movimentos femininos e os que simpatizam com a causa das mulheres. Assim procedia, por exemplo, a paraibana e educadora Alice Alfredo M onteiro: 


\section{DECRETO № 21.076 - DE 24 DE FEVEREIRO DE 1932}

O Chefe do Governo Provisório da República dos Estados Unidos do Brasil

Decreta o seguinte:

\section{CÓDIGO ELEITORAL}

PARTE PRIMEIRA

Introdução

Art. 10 Este Código regula em todo o país o alistamento eleitoral e as eleições federais, estaduais e municipais.

Art. 2 ํ É eleitor o cidadão maior de 21 anos, sem distinção de sexo, alistado na forma deste Código.

Art. $3^{\circ}$ As condições de cidadania e os casos em que se suspendem ou perdem os direitos de cidadão, regulam-se pelas leis atualmente em vigor, nos termos do decreto no 19.398, de 11 de novembro de 1930, art. 4으, entendendo-se, porem, que:

a) o preceito firmado no art. $69, \mathrm{n}$ - 5, da Constituição de 1891, rege igualmente a nacionalidade da mulher estrangeira casada com brasileiro;

b) a mulher brasileira não perde sua cidadania pelo casamento com estrangeiro;

c) o motivo de convicção filosófica ou política é equiparado ao de crença religiosa, para os efeitos do art. 72 , $§ 29$, da mencionada Constituição; d) a parte final do art. $72, \S 29$, desta, somente abrange condecorações ou títulos que envolvam foros de nobreza, privilégios ou obrigações incompativeis com o serviço da República.

- A mulher adquiriu com o correr dos tempos a cultura, que antes era propriedade exclusiva do homem.

D esde que à mulher é permitido fazer os mesmos cursos, estudando nas mesmas escolas que o homem, não se poderia admitir que Ihe fosse eternamente vedado exercer os direitos correspondentes à cultura conquistada ${ }^{13}$.

Para muitas das que responderam à enquete, as mudanças acerca do lugar e da função da mulher na sociedade brasileira, em fase de crescente urbanização e industrialização, especialmente da mulher da elite social, bem como no seu padrão de comportamento, eram explicadas, sobretudo, como uma questão de aquisição de cultura, entendida como saber, ilustração, um corpo de conhecimento formal: 
A mulher brasileira deve votar porque deixou de ser a mulher da época da colônia, da qual apenas se exigia graça e beleza. A mulher brasileira de hoje, pensa, estuda. Mulher de espírito forte conservando [...] os sentimentos da honra e do dever ${ }^{14}$.

A insistência dada ao aspecto cultural da questão encontrava sua razão de ser em um viés do pensamento dominante da época, por muito tempo corroborado pelos cânones científicos, segundo o qual o cérebro da mulher seria inferior ao do homem. $O$ psiquiatra $\mathrm{M}$ iguel Bombarda foi um dos que teorizou sobre 0 assunto, afirmando a inferioridade da mulher com base nas teorias evolucionistas. D izia ser o cérebro feminino mais leve e com menos circunvoluções, o que gerava a suposta fragilidade feminina, tese cientificamente contestada, porém, pela anarquista mineira M aria L acerda de M oura e pela médica Alzira R eis ${ }^{15}$.

Tal como acontecia em relação a outros fenômenos sociais, também convertidos em objetos de investigação científica da etnologia e da sociologia, como a questão racial, por exemplo, as desigualdades e diferenças percebidas no modo de pensar entre homense mulheres passavam a ser vistas fundamentalmente como um problema de herança cultural e modo de vida, e não como um determinismo biológico ${ }^{16}$.

M esmo havendo sido provada cientificamente a capacidade intelectual da mulher, como o demonstrava, por exemplo, Tito Lívio de Castro, no livro A mulher ea sociogenia, citado em entrevista pela senhora I sabel O rlando Andrade B ezerra, ainda assim, por que havia os que não acreditavam na capacidade intelectual da mulher? A história do mundo ocidental estava repleta de casos de mulheres bem sucedidas nas diversas áreas das artes, da cultura e do conhecimento científico; mulheres que sobreviveram do fruto de seu trabalho e com o concurso de suas inteligências ${ }^{17}$. A doutora Albertina Correia Lima expunha seu pensamento sobre a questão, com muita clareza e objetividade: " A mulher brasileira deve ali representar-se não só para defender seus direitos, tanto tempo esquecidos, como para afirmar mais vitoriosamente sua capacidade mental" 18 . Para Lili Lages, a sólida educação e uma conveniente ilustração eram consideradas condição sinequa non para a mulher alcançar a independência econômica, esta sim, " base imprescindível a to das as outras vitórias" 19.

Procriar, educar os filhos para bem servir à pátria e encarregar-se da administração e economia domésticas, eis as atividades que a sociedade e os valores tradicionais haviam reservados às mulheres, confinando-as ao espaço da casa e da vida privada ${ }^{20}$. Se tal situação apresentava sinais de mudanças, visíveis nas grandes capitais brasileiras, especialmente nas da atual região Sudeste, o mesmo não acontecia nas cidades de menor porte e menos urbanizadas do país. M esmo no Recife, a terceira cidade do Brasil em termos de população e de economia, as mulheres diziam encontrar resistência para se impor profissionalmente, em ambientes para além do recôndito do lar. I da M arinho Rego, diretora da Escola T écnico Profissional M asculina, posto "para que um homem deveria parecer mais bem indicado", segundo comentário do Diario dePernambuco, mas no desempenho 
do qual vinha demonstrando "apurado senso administrativo, um dinamismo de ação eficiente e produtivo", além de uma inteligência esclarecida, esta senhora denunciava:

No Brasil, principalmente nas capitais do norte, devemos todas ser domésticas. D omésticas têm aqui um duplo sentido. Q uer dizer ao mesmo tempo do lar, da família - mulher quituteira, que não lê, não escreve e, sobretudo, não pensa. 0 outro sentido ainda é mais interessante, porque nos equipara a quase generalidade dos animais inferiores. D omésticas quer então dizer autômatas, submissas, escravas ${ }^{21}$.

Eram tempos de mudanças, de luta pela conquista da liberdade feminina, no dizer de algumas entrevistadas, em que o novo não se havia ainda definido e consolidado. As transformações relativas ao papel social da mulher, incluindo sua atuação na vida política, eram percebidas e explicadas em termos do fluir histórico, discurso a que tivemos acesso através da fala de Edwiges de Sá Pereira, quando discorria sobre a primeira categoria de mulher brasileira: a que não precisava trabalhar para sobreviver. Entusiasmada pela campanha abolicionista - marco inaugural do movimento feminista no país, segundo se depreende dos seus estudos -, a mulher emancipada se foi desvencilhando gradativamente os afazeres domésticos, que a absorvia quase por completo, sendo atraída e seduzida por atividades situadas na esfera da vida coletiva pública. A passagem da vida doméstica, privada e familiar, para a coletiva, pública e social, processara-se mediante 0 ingresso nas associações religiosas, a princípio, e nas de caridades, em seguida:

E esta personalidade, solicitada pelos reclamos da vida prática e útil, que entrou a conhecer de perto e com a qual se identificou, foi a pouco e pouco se desdobrando, a pouco e pouco ingressando nas atividades fora do lar. As associações religiosas a princípio, depois a caridade associada: os orfanatos, os asilos, a creche, as escolas, os comites patrióticos, por fim bastaram-lhe até certo tempo. $\mathrm{H}$ oje, mais não. $\mathrm{H}$ oje a mulher que pode não limita sua ação: ela projeta para um destino de maior expansão as iniciativas de que se sente capaz ${ }^{22}$.

As mudanças nas áreas de atuação da mulher e nos padrões de comportamento feminino eram correlacionadas às conquistas tecnológicas mundiais - à eletricidade, à aviação, aos avanços na indústria de eletrodoméstico, que, ao tornar mais ágil o serviço no interior do lar, permitiu à mulher urbana das camadas médias dispor de mais tempo livre para si. Associadas, também, a maior facilidade nas comunicações, quando se assistiu a uma multiplicação de novos títulos na imprensa de periódicos, ao surgimento do rádio e à consagração do cinema como veículo de mais viva penetração entre os vários segmentos e categorias da sociedade. M odificações que vinculavam a uma memória da vida em sociedade de mais curto alcance, como lembrava a senhora Andrade Bezerra:

[...] mas, veio a terrível guerra de 1914 e, enquanto lá nas trincheiras, os homens se batiam, ela, num esforço sublime, rebentava os elos das cadeias e heroicamente ocupava os lugares vazios dos companheiros, no comércio, na agricultura, nas indústrias, fazendo surgir, desassombrada e majestosa, a personalidade feminina ${ }^{23}$. 
Para muitos, inclusive mulheres, as recentes conquistas femininas na política, no direito, no trabalho, representavam uma ameaça. M ais que uma possível e indesejada concorrência com o elemento masculino nos domínios agora compartilhados, temiam que as novas ocupações as fizessem desinteressar-se pelos assuntos domésticos. Temiam a desestruturação da família, célula mater da sociedade, a desintegração do lar, a desmoralização dos costumes, o abandono dos princípios éticos e religiosos católicos. As próprias mulheres, porém, ao menos aquelas que participaram da enquete de 1933, as mais e as menos empolgadas com a luta e as conquistas da mulher, com o seu direito ao voto e participação na política, afirmavam que as mudanças não significavam uma ruptura brusca e completa com o passado, com a forma de organização da vida social e com os valores tradicionais que nortearam suas existências até então. $\mathrm{N}$ ão viam incompatibilidade entre ter uma casa, marido e filhos e exercer a cidadania política, materializada pelo exercício do voto livre, ou atuar profissionalmente fora do $\operatorname{lar}^{24}$. Contestavam o modo de pensar dos que se assustavam com as perspectivas de mudanças: "Q uando o homem afirma que a vida de sua companheira só pode ser exclusivamente dedicada ao lar, à educação dos filhos [...], fal ha na compreensão." E mais: "A brasileira não idealiza, não deseja um feminismo individualista, egoístico, como o soviético, passando ao Estado suas obrigações" ${ }^{25}$.

Embora tecesse considerações de várias ordens - não acreditasse que a mulher brasileira ingressasse na política com forte entusiasmo, haja vista a forma como ela, a política, se organizava no Brasil, voltada para a defesa de interesses mediatos e particulares e para as competições locais, muito longe de aqui se praticar uma verdadeira "ciência política"; e dada a exigüidade do meio intelectual feminino -, ainda assim, $\mathrm{N}$ air de Andrade defendia o voto da mulher. $\mathrm{M}$ as, sublinhava: " $\mathrm{H}$ á ainda a observar - ponto mais importante - que a mulher abraçando deveres de ordem coletiva, não poderá negligenciar os deveres da ordem individual o que seria falsear sua finalidade verdadeira no lar, na família" ${ }^{26}$.

A mulher brasileira, portanto, pertencente às camadas sociais mais favorecidas, deveria atuar no mundo moderno capitalista acumulando uma dupla função: a de dona de casa e educadora dos filhos e a de cidadã consciente de seus deveres e responsável pelo destino da pátria. Conciliar razão e sentimento, colocar à disposição da coletividade a intuição, dom natural atribuído ao sexo e do qual as mulheres não davam mostras de quererem desvencilhar-se. "O sufrágio feminino escreverá decerto na história brasileira a página do coração", sentenciava a mesma $\mathrm{N}$ air de Andrade ${ }^{27}$.

Esta mulher, entretanto, para ser merecedora do voto e bem representar a categoria na vida pública, deveria preencher certos requisitos morais, intelectuais e profissionais, dos quais passaremos a falar, sempre referenciados pela enquete do Diario de Pernambuco.

Considerando o lugar de classe social de onde falavam e os valores morais e culturais das entrevistadas, a representante da mulher na futura Constituinte 
teria, necessariamente, que ser inteligente, culta, possuir idoneidade moral e reconhecida competência no ramo da atuação profissional que abraçara ou influência no meio social por onde circulava ${ }^{28}$. Bastante representativa do modo de pensar dessas mulheres, era a declaração coletiva dada ao jornal pela Federação Pernambucana para o Progresso Feminino, que reuniu mais de duzentas e vinte e oito assinaturas: "A uma forte inteligência deve aliar-se sólida cultura, aprimoradas ambas por uma perfeita educação religiosa, cívica, e comprovado senso de equilíbrio" 29 .

A particularidade do momento político que o país experimentava, há pouco sacudido por uma revolução, vivendo em pleno processo de reconstitucionalização, de redefinição do Estado nacional e de reorganização da vida política, mostrava-se mais que propícia à participação feminina. N essa conjuntura, a muIher, desde que regida pelos princípios religiosos e morais católicos, teria uma contribuição única e original a dar. E mais, atuaria quase que como uma salvadora da pátria, segundo se depreende da fala da senhora Agnaldo Lins:

E $m$ tese: à mulher, que já tem sobre seus ombros a grande responsabilidade da construção da família nos sãos princípios da moral cristã, não devia caber também a função de cuidar das coisas públicas. No entanto acho que a mulher não deve negar sua colaboração sempre que for julgada necessária."

Q uem sabe se a colaboração feminina neste momento de instabilidade do país, não será o raio de luz que com o seu proverbial otimismo desvaneça todas as preocupações, resolva todos os problemas, abra enfim todos os caminhos. Admitamos o voto feminino como medida de emergência. $N$ esta época, que podemos considerar como a mais triste do mundo, em que se produz tão desconcertante conflagração de idéias, de sentimentos, de antíteses morais, a contribuição de todas se faz necessária, num arranco supremo de levantamento dos sãos princípios, reunindo sob a mesma bandeira todas as criaturas sem exceção de nascimento, cor, herança, sexo ${ }^{30}$.

Esta mulher, de classe média ou de elite, escolarizada, inteligente, exercendo profissão fora do lar, geralmente integrada a alguma associação feminina de fundo católico, parecia como que predestinada a elaborar uma dupla missão: mostrar serem compatíveis as atividades do mundo privado com as do público; e reconciliar a política com a religião católica, reconduzindo esta última para o interior do Estado nacional, de onde havia sido banida desde 1891. A tônica dada aos princípios católicos constituiu um diferencial do movimento feminista em Pernambuco, distinguindo-se, neste ponto, da posição adotada pela direção nacional da Federação Brasileira pelo Progresso Feminino; fato que está por merecer análise mais aprofundada ${ }^{31}$.

A Constituição de 1891, a primeira da República brasileira, de inspiração jacobina, possuía caráter inteiramente laico. Em seu preâmbulo, diferentemente das que a antecederam e mesmo das que viriam a sucedê-las nas décadas seguintes, não há referência a D eus. N as D eclarações de D ireito, no § 3o , estabelecia que "Todos os indivíduos e confissões religiosas podem exercer pública e livre- 
mente 0 seu culto, associando-se para esse fim e adquirindo bens, observadas as disposições dos direitos comuns." Com relação ao casamento, a lei era clara: "A República só reconhece o casamento civil, cuja celebração será gratuita." Sobre os cemitérios, dizia, "terão caráter secular e serão administrados pela autoridade municipal", ficando livre to do os cultos religiosos, desde que não ofendessem a moral pública e as leis. 0 § 6 o dizia: "Será leigo o ensino ministrado nos estabelecimentos públicos", e o seguinte legislava que "N enhum culto ou igreja gozará de subvenção oficial, nem terá relação de dependência ou aliança com o governo da união, ou dos Estados" 32 .

Para alguns segmentos da sociedade, a R evolução de 1930 acenara com a possibilidade de a I greja Católica vir a recuperar espaços e poder, sobre a vida política e sociedade civil, perdidos desde que R epública liberal se instalara. N este sentido, ela apresentava um viés mais que conservador, reacionário. 0 mundo católico reagia, mobilizava esforços, arrebanhava suas ovel has e conclamava-as à luta. O rganizava ou estimulava o surgimento de associações femininas, a exemplo da Federação Pernambucana para o Progresso Feminino, da Liga Eleitoral C atólica e da C ruzada de E ducadoras Católicas.

O Diario, ampliando a cobertura dada ao tema da mulher e a política, acompanhou o trabal ho de propaganda e alistamento eleitoral posto a cabo pela Liga Eleitoral Católica, na paróquia das Graças. Atividade que ficou registrada, em fotografia, flagrando três moças em plena campanha pelas ruas do bairro homônimo. 0 trabalho das propagandistas constituía em realizar palestras nos centros so ciais e em visitar as famílias, de casa em casa, indagando se os adultos já se haviam alistados. Caso não, iniciavam um jogo de sedução e convencimento dos potenciais eleitores, visando a quebrar a indiferença pelo exercício do voto livre, verificada entre homens e mulheres, e a induzi-los a votar nos candidatos indicados pela Liga, todos católicos, evidentemente ${ }^{33}$.

0 voto feminino e a Constituinte próxima vinham reforçar a luta da I greja em sua busca por reaver espaços perdidos. As palavras de C elina D idier, professora de ensino religioso em escola particular do Recife e membro da Cruzada de E ducadoras $C$ atólicas, traduziam bem o jogo de interesses políticos nutrido pela I greja em relação ao voto feminino, e as expectativas das mulheres, de que vimos nos ocupando, de ver restabelecidos os costumes sociais baseados nos princípios morais e éticos do catolicismo:

E com tal programa, a mulher irá lembrar que, se na Velha República por circunstâncias diversas, não reagiu contra a organização laica da Constituição, hoje, vem reclamar para a Constituinte em projeto, bases seguras de justa equidade, cuja ausência acarretou conseqüências nefastas ${ }^{34}$.

O "mundo católico feminino", dizia nossa conhecida informante $\mathrm{N}$ air de Andrade, "tem no momento deveres imperiosos para chegar às urnas". M oralizar a sociedade brasileira, fragilizada em seu organismo social, resultado de décadas vivendo sob domínio de uma ordem social e política laica, eis o dever das 
mulheres católicas: "Somos católicas e não compreendemos as reivindicações femininas fora desses princípios. Somos pela indissolubilidade do matrimônio como condição máxima de garantia da família, da estabilidade do lar, da moral social enfim" ${ }^{35}$. U ma única entrevistada, a senhora E dna L eite Gueiros, ao manifestar sua intenção de voto, fez interessante ressalva: votaria em Edwiges de Sá Pereira, "contanto que ela não fosse combater o divórcio ou submeter-se às exigências dogmáticas da igreja [...]" ${ }^{36}$.

As bases jurídicas em que se assentava o casamento civil, por sua vez, necessitavam urgentemente ser revistas e reformadas pela nova Constituição. As muIheres consultadas pelo jornal condenavam o Código Civil, em vigor desde 1916, que retirava direitos da mulher casada, colocando-a em situação de inferioridade e dependência em relação ao cônjuge. Esta foi, inclusive, a tônica da entrevista dada pela advogada paraibana Lilia Guedes, ao Diario de Pernambuco: " $\mathrm{N}$ a fase de reorganização social que atravessamos a maior conquista por que se deve bater a mulher é a de manter a plenitude de sua capacidade civil no casamento." A mulher solteira gozava de maior extensão de direitos que suas irmãs casadas, 0 que the parecia, além de grande injustiça, contraditório em relação à recente conquista feminina de direito ao voto e à plena cidadania política ${ }^{37}$.

Em convenção realizada no Rio de Janeiro, a Federação Brasileira para o Progresso Feminino buscou traçar o seu programa para as eleições que se avizinhavam. T rataria dos interesses das " mães de família, donas de casa, empregadas públicas e comerciais, professoras, operárias, enfim todas as mulheres que trabaIham." A sucursal pernambucana, que se fez representar pelas senhoras G eorgina Barbosa e Laura Austragésilo, apresentou e defendeu as seguintes propostas: "apoio radical aos princípios católicos; inclusão das obras contra as secas na C onstituição como medida de interesse nacional; combate à idéia de militarização da mulher" ${ }^{38}$. Recomendou às votantes e simpatizantes da causa, a candidatura de E dwiges de Sá Pereira, que, filiada ao Partido E conomista, não alcançou número suficiente de votos para eleger-se deputada. Em todo o país, apenas uma mulher conseguiu assento na Assembléia Constituinte: C arlota Pereira de Q ueiroz, eleita por São Paulo. Berta L utz, candidata pela legenda do Partido Autonomista do D istrito Federal, como representante da Liga Eleitoral Independente, entidade por ela criada também em defesa dos direitos da mulher, em 1932, obteve a primeira suplência e, em 1936, ocupou uma cadeira na Câmara, em virtude da morte do titular, deputado C ândido Pessoa.

A I greja saiu vitoriosa em sua luta, recuperando poder e prestígio perdidos desde 1891. A Carta M agna de 1934 introduzia seu texto dizendo: "N ós, os representantes do Povo Brasileiro, pondo a nossa confiança em D eus, reunidos em Assembléia $\mathrm{N}$ acional constituinte [...]"39. O casamento continuou a ser civil, e gratuita a sua cel ebração; porém, produziria os mesmos efeitos se realizado por ministro de qualquer igreja, desde que não contrariasse a ordem pública ou os bons costumes. 0 divórcio, que tanto atemorizava as mulheres católicas, não 
fora aprovado, permanecendo indissolúvel o laço matrimonial. 0 ensino religioso passou a ser de freqüência facultativa nas escolas particulares, mas tornou-se matéria dos horários nas escolas públicas primárias, secundárias, profissionais e normais.

As mulheres permaneceram em luta, organizadas em suas associações, buscando avançar em suas conquistas por direitos civis, políticos, trabalhistas. Em 1937, porém, com o golpe de Estado que instalou a ditadura no Brasil, Getúlio Vargas extinguiu os partidos políticos do país, incluindo, nos dispositivos legais, as organizações civis nos termos da hipótese expressa de registro civil. Em conseqüência, foram dissolvidas diversas asso ciações civis, dentre as quais a Federação Pernambucana para o Progresso Feminino, assim permanecendo até que passasse a existir "sob diferente denominação, dentro da finalidade que sempre observou, puramente cultural e beneficente" 40 . As mulheres da classe média e da elite urbanas se manteriam unidas e organizadas em associações, sob inspiração da I greja Católica ou diretamente tuteladas por ela, lutando sobretudo pela moralização dos costumes, pelo fortal ecimento da família e pela difusão dos princípios éticos e valores católicos, a exemplo da Campanha Pró-D ecência na Praia, iniciada no Recife, em 1939.

\section{N otas}

10 Diario de Pernambuco foi fundado em 1825. Sediado no Recife, é o jornal mais longevo da América Latina, ainda em circulação. Sobre este órgão da imprensa, ver obra organizada por G ilberto Freyre (1979, E dição fac-símile) para marcar o centenário do jornal e $\mathrm{N}$ ascimento (1968).

2 A segunda categoria era a das mulheres que precisavam e sabiam trabalhar e a terceira a das que precisavam e não sabiam trabalhar. Edwiges de Sá Pereira era escritora, membro da Academia Pernambucana de Letras e professora da Escola N ormal. Líder do movimento feminino em Pernambuco, foi uma das fundadoras da Federação Pernambucana para o Progresso Feminino, em 1931. Concorreu às eleições para a Assembléia N acional Constituinte de 1934, pelo Partido E conômico, não conseguindo, porém, eleger-se. Ver Pereira (1932). D ados biográficos de Edwiges de Sá Pereiras encontram-se em Schuma e Schumaher, 2000, p. 189.

Todas as citações dos documentos originais, aqui citados, tiveram sua grafia atualizada.

3 Sobrea participação feminina no movimento abolicionista em Pernambuco, ver Ferreira, 2000.

4 "O significado jurídico-político maior da convocação de uma assembléia nacional constituinte é, então, a restauração da legalidade e da legitimidade do poder, fazendo-o passar de um poder de fato, de um regime de força, a um poder de direito, a um regime legal." Gomes et al., 1981, cap. I.

5 Permaneciam excluídos do direito de voto os mendigos e analfabetos, os praças de pré e os clérigos regulares. A Constituinte de 1934 não instituiu a obrigatoriedade do alistamento e do voto. À guisa de comparação, a França estabeleceu o voto feminino apenas em 5 de janeiro de 1944 . 
6 N o M anifesto regionalista de 1926, G ilberto Freyre registrou as mudanças ocorridas nos valores, comportamentos e lugar social da mulher, entre as décadas de 1920 e 1930, não sem lamentar a perda de vitalidade de certos modos e costumes predominantes na sociedade escravista e patriarcal: “As novas gerações de moças já não sabem, entre nós, a não ser entre a gente mais modesta, fazer um doce, um guisado tradicional e regional. Já não tem gosto nem tempo para ler os velhos livros de receitas da família. Q uando a verdade é que, depois dos livros de missas, são os livros de receita de doces e guisados os que devem receber das mulheres leitura mais atenta. 0 senso de devoção e o de obrigação devem completar-se nas mulheres do Brasil, tornando-as boas cristãs, e, ao mesmo tempo, boas quituteiras, para assim criarem melhor os filhos e concorrerem para a felicidade nacional. $\mathrm{N}$ ão há povo feliz quando às suas mulheres falta a arte culinária. É uma falta quase tão grave como a fé religiosa". Freyre, 1996.

7 Andrade, 1933, p. 1. D oravante, quando se tratar de respostas à enquete, não mais Ihe repetiremos o título, mas apenas o nome da entrevistada, o jornal e a data da publicação.

8 A primeira mulher a votar, no Brasil, foi Celina Guimarães Viana, professora do município de M ossoró, no Rio G rande do N orte, que conseguiu, na justiça local, o direito de voto. Berta M aria J úlia L utz, bióloga, nasceu em São Paulo, em 1894. Estudou na Europa, absorvendo idéias em torno das lutas feministas e, de volta ao Brasil, em 1918, criou a Liga para a E mancipação das M ulheres, tornando-se pioneira nas lutas feministas no país. Para maiores informações, consultar verbetes "Federação Brasileira pelo Progresso Feminino" e "Berta L utz", no Dicionário das mulheres do Brasil: de 1500 até a atualidade bi ográfi co e ilustrado..., respectivamente, pp. 217-226 e 106110. Ver também O liveira, 1992, pp. 534-535.

9 Lages, 1933, p. 1. Lili Lages, primeira presidente da Federação Alagoana para o Progresso Feminino, foi eleita deputada a Assembléia Constituinte de Alagoas, em 1934, sendo uma das nove mulheres brasileiras que alcançaram sucesso nas urnas, concorrendo às constituintes de seus respectivos Estados. D ici onário dasmulheres do Brasil: de 1500 até a atualidade biográfico eilustrado..., pp. 333-334.

10 A sucursal pernambucana da Federação Brasileira para o Progresso Feminino foi fundada em 1931, por iniciativa de um grupo de mulheres, tendo à frente E dwiges de Sá Pereira. Ver Livro deA tas da A ssembléia Geral eSessõesExtraordinárias da Feder ação Pernambucana pelo Progresso Feminino. 1931-1937. Arquivo Edwiges de Sá Pereira. Acervo Fundação J oaquim N abuco. Sobre os movimentos femininos e feministas no mundo ocidental e no Brasil, ver D uby e Perrot (orgs.), 1991 e Priori (org.), 1997.

11 Campos, 1933, p. 1.

12 Gueiros, 1933, p. 1.

13 M onteiro, 1933, p. 1.

14 I dem.

15 N osso Século, 1981, vol. 2. Ver especialmente o capítulo IV, “O sexo frágil e o sportman", pp.100-127.

16 Esta mudança ocorrida na base do pensamento sociológico brasileiro, que teve, entre seus marcos, obras de Gilberto Freyre escritas nas décadas de 1930 e 1940, como Casa grande \& senzala e Sobradose mucambos, pode ser percebida nesta passagem: “[... ] a verdade é que a especialização do físico e moral da mulher, em criatura franzina, 
neurótica, sensual, religiosa, romântica, ou então, gorda, prática e caseira, nas sociedades patriarcais e escravocráticas, resulta em grande parte, dos fatores econômicos, ou antes, sociais e culturais, que a comprimem, amolecem, alargam-Ihe as ancas, estreitam-Ihe as cinturas, acentuam-Ihe 0 arredondado das formas, para melhor ajustamento de sua figura aos interesses do sexo dominante e da sociedade organizada sobre o domínio exclusivo de uma classe, de uma raça, de um sexo." Freyre, 1985, t. I, p. 96.

17 D epoimento da senhora Andrade Bezerra, 1933, p. 1.

18 L ima, 1933, p. 4.

19 Lages, 1933, p. 1.

$20 \mathrm{M}$ aluf e M ott, 1998, pp. 367-421.

21 Rego, 1933, p. 1.

22 Pereira, op. cit., p. 7.

23 Bezerra, 1933, p. 1.

24 Gueiros, 1933, p. 1.

25 Bezerra, 1933, p. 1. Em seu depoimento, O lga Pimentel, escriturária do Tesouro do Estado, teceu comentários bastante originais em relação às demais. Afirmou encantar-se com as mulheres que se dedicavam exclusivamente ao lar, indo de encontro à tendência modernizante nos valores e comportamentos femininos. Para ela, a mulher se havia encaminhado para o mercado de trabalho não para conquistar a liberdade sonhada, mas forçada pelas dificuldades econômicas: "I nfelizmente, porém, a questão econômica tem atirado a mulher para o meio da rua, para o esforço do trabalho em parceria com o homem, dourando-se a pílula dessa amarga realidade com o colorido de que assim a mulher adquire a sua liberdade." Certamente, referia-se a mulheres de classe média ou mesmo pobres, àquelas que precisavam e sabiam trabalhar, para voltarmos à classificação de E dwiges de Sá Pereira. Pimentel, 1933, p. 1.

26 Andrade, 1933, p. 1.

27 D entre as vantagens que $\mathrm{N}$ air de Andrade via na mulher, para atuar no universo da política, estavam o sentimentalismo e o poder de intuição: “A mulher mais intuitiva que o homem, possui em maior escala esse dom misterioso, sutil - o poder de seleção por vezes grandemente necessário nas demarches políticas."

28 Apenas uma, dentre matérias que compunham a série, incluindo a propaganda da Federação Pernambucana para o Progresso Feminino, publicada na seção "Solicitada" , observava: "H á uma grande distância entre um espírito esclarecido e uma tendência especial para bem representar uma classe." N ão se referia, porém, à classe social, e sim, ao gênero feminino. Cunha, 1933, p. 1.

29 D eclaração Coletiva da Federação Pernambucana para o Progresso Feminino. Diario de Pernambuco. Recife, 29 jan. 1933, p. 1.

30 Lins, 1933, p. 1.

31 A proposta das feministas para a redação do anteprojeto de constituição, de cuja comissão participou Berta L utz, incluía treze itens, nenhum dos quais fazia qualquer alusão a aspectos religiosos: "E nfatizava as questões diretamente vinculadas ao cotidiano das mulheres - como a maternidade e proteção à infância - e contemplava problemas que afetavam as condições de vida da população pobre como um todo. 
Pensando de forma ampla e com ousadia para a época, as feministas condenaram as diferenças salariais motivadas por sexo, nacionalidade ou estado civil, previram a instituição de licença maternidade remunerada, além de pleitearem o acesso irrestrito de mulheres a cargos públicos, sem distinção de estado civil." D i ci onário dasmulheresdo Brasil: de 1500 atéa atualidade biográfico eilustrado..., p. 221.

32 Constituição da R epública dos Estados U nidos do Brasil de 24 de Fevereiro de 1891. Em Almeida, 1961, pp. 101-143. Para a Seção II, Declaração de Direitos, ver pp. 131-132. Para a reação provocada entre o episcopado católico, ver Rodrigues, 1981.

33 "O movimento católico feminino no R ecife em face às próximas eleições constituinte". Diario dePernambuco. Recife, 31 jan. 1933, p. 1.

34 Didier, 1933, p. 3.

35 Pereira, 1933, p. 1. Para uma análise recente da tentativa de moralização da sociedade brasileira, com base em valores modernos e religiosos católicos, ver N ovaes e M ello, 1998, pp. 559-658.

36 Gueiros, 1933, p. 1.

37 Guedes, 1933, p. 1. Código Civil, 1992, pp. 7-257. Sobre o casamento civil e os direitos dos cônjuges, ver M aluf e M ott. op. cit., especialmente, pp. 373-384. Esta percepção, expressa por mulheres que responderam à enquete do jornal, distinguiase da registrada em abaixo-assinado colhido pelas lideranças feministas da Federação Brasileira para o Progresso Feminino, em 1927, apresentado à Comissão de Constituição e J ustiça do Senado, por ocasião da votação de matéria relatada por C hermont. Trecho do documento dizia: "O nosso Código Civil, afastando-se de outros menos liberais, deu à mulher brasileira uma situação privilegiada, considerando a esposa como companheira do marido e não como sua inferior, não lhe exigindo na sociedade conjugal obediência, mas sim colaboração. Sendo a mãe a tutora natural dos filhos, dotada de pátrio poder, elevou-se legalmente ao nível dos homens, cujas responsabilidades políticas está habilitada a compartilhar. [...]". D i cionário das mulheres do Brasil: de 1500 atéa atualidade biográfico eilustrado..., p. 220.

38 Pereira, 1933, p. 1.

39 Constituição da República dos Estados U nidos do Brasil de 16 de Julho 1891. Em Constituições do Brasil..., pp. 227-336.

40 Ata da sessão extraordinária da diretoria da Federação Pernambucana pelo Progresso Feminino, realizada para tomar conhecimento da situação da mesma e deliberar a respeito. Recife, 6 de dezembro de 1937. In Livro de Atas da Assembléia Geral e Sessões Extraordinárias da Federação Pernambucana pelo Progresso Feminino. p. 20-23. Arquivo Edwiges de Sá Pereira. Acervo Fundação J oaquim N abuco.

R eferências bibliográficas

CON STITUIÇÃO da R epública dos Estados U nidos do Brasil de 24 de Fevereiro de 1891. Em M EN DES, Fernando H. (O rganização, revisão e confecção dos índices). Constitui ções do Brasil. 3ạ ed revista e atualizada, São Paulo, Saraiva, 1961. 
DIA RIO de Pernambuco. Recife, 26 jan.-4 abr. 1933.

DU BY, G eorges e PERROT, M ichelle (orgs.). H istória dasmulheresno O cidente. Porto, Afrontamento, 1991, $5 \mathrm{v}$.

FAU ST O, Boris (dir.). O Brasil R epublicano, Sociedade e Política (1930-1964), t. III, vol. III. por Ângela M aria Castro Gomes, Dulce Chaves Pandolfi, Maria H elena Bousquet Bomeny et al. São Paulo, DIFEL, 1981.

FERREIRA, Luzilá Gonçalves (org.) Suaves amazonas. Recife, Editora U niversitária, 2000.

FREYRE, Gilberto (org.). Livro do N ordeste. 2a ed., Recife, Arquivo Público Estadual, 1979. (Ed-fac-símile).

. Sobrados e mucambos: decadência do patriarcado rural edesenvolvi mento do urbano. 7ạ ed., Rio de Janeiro, J osé Olympio, 1985.

. M anifesto regi onalista. O rganização e apresentação de Fátima Q uintas; prefácio de Antônio Dimas. 7ạ ed. revisada e aumentada. Recife, Fundaj/ M assangana, 1996.

LIVR O deA tasda A ssembléia Geral eSessõesExtraordináriasda Federação Pernambucana pelo Progresso Feminino. 1931-1937.

MALUF, M aria e MOTT, M aria Lúcia. "Recônditos do mundo feminino". Em SEVCENKO, Nicolau (org.). H istória da vida privada no Brasil. São Paulo, Companhia das L etras, 1998 (H istória da vida privada no Brasil, 4 vols.).

NASCIMENTO, Luiz do. H istória da imprensa em Pernambuco (1821/ 1954). 2a ed., Recife, U niversidade Federal de Pernambuco, 1968. (Diario de Pernambuco, 1).

N OSSO Século. São Paulo: Abril Cultural, 1981, 5 vols.

N O VAES, Fernando Antônio e M EL LO , J oão M anuel C ardoso de. "C apitalismo tardio e sociabilidade moderna". Em SCH WARCZ, Lilia M oritz (org.). H istória da vida privada no Brasil. São Paulo, Companhia das Letras, 1998 (H istória da vida privada no Brasil, 4 vols.).

O LIVEIRA, J osé Teixeira (org.). Dicionário brasileiro de datashistóricas. 3ạ ed. refundida, ampliada e atualizada, Belo H orizonte/ Rio de J aneiro, I tatiaia, 1992.

O LIVEIRA, Juarez de (O rganização dos textos, notas remissivas e índices). Código Civil. 7a ed., São Paulo, Saraiva, 1992 (L egislação Brasileira).

PEREIRA, Edwiges de Sá. "Pela mulher, para a mulher". Trabalho apresentado ao Se gun do C ongresso I nternacional Feminino. Recife, O fficinas Graphicas da Boa I mprensa, 1932.

PRIORI, M ary D el (org.). H istória dasmulheresno Brasil. São Paulo: Contexto, 1997.

RODRIGUES, Anna M aria (seleção e organização). A I greja na R epública. Brasília, UnB, 1981. (Pensamento Político Republicano, 4).

SCHUMA E SCHU M AHER, Érico vital Brasil. Dicionário das mulheres do Brasil: de 1500 até a atualidade (biográfico e ilustrado). Rio de J aneiro, Jorge Zahar, 2000.

R ESU M O - ESTE artigo trata da participação política da mulher, no quadro das transformações trazidas pela Revolução de 1930 e, sobretudo, pela perspectiva da eleição da Assembléia N acional Constituinte, em 1934. Situado no campo da chamada microhistória, a 
análise está baseada nos resultados de uma enquete, real izada pelo D iario dePernambuco, no início de 1933. D ezenove mulheres de classe média e da elite urbanas de Pernambuco, Paraíba e Alagoas, e duas associações femininas foram ouvidas pelo jornal, a propósito do momento político, das tarefas da futura Constituinte, do papel político e do lugar que julgavam dever ser o da mulher no processo de transformação vivenciado no Brasil, naquele período. Este importante e pouco conhecido material foi tratado com o objetivo da fazer falar as depoentes de então, embora trazendo o aporte histórico que as situa e as contextualiza.

A BSTRACT - this article analyzes the political participation of women, in the set of deep changes brought by the Revolution of 1930 and, especially, by the perspective of the elections to the $\mathrm{N}$ ational Constitutional Assembly in 1934. This analysis, of the so-called micro-history style, is based on the results of a research conducted by the daily newspaper Diário dePernambuco, in the beginning of 1933. N ineteen middle and upper class women of Pernambuco, Paraíba e Alagoas, as well as two women's associations, were interviewed on the political momentum, the task of the future Assembly, the political role and the space they believed women should occupy in the changing Brazilian scene of the 30's. This important, and widely unknown, material was studied with the purpose of enabling the original interviewees to speak up their minds, given the due consideration of their context.

Rita de Cássia Barbosa de A raújo é doutora em H istória Social pela U niversidade de São Paulo, pesquisadora e diretora do Instituto de D ocumentação da Fundação J oaquim Nabuco.

A autora agradece a Bárbara Branco Alves, estagiária na área de $\mathrm{H}$ istória, na $\mathrm{F}$ undação Joaquim $\mathrm{N}$ abuco, pela pesquisa realizada na coleção de microfilmes do Diario de Pernambuco.

Texto recebido e aceito para publicação em 30 de setembro de 2003. 